\title{
A 'key to all quotations'? A corpus-based parameter model of intertextuality
}

Regula Hohl Trillini and Sixta Quassdorf

Department of English, University of Basel, Basel, Switzerland

Abstract

Categorization and taxonomy are topical issues in intertextuality studies. Instead of increasing the number of overlapping or contradictory definitions (often established with reference to limited databases) which exist even for key concepts such as "allusion" or "quotation", we propose an electronically implemented data-driven approach based on the isolation, analysis and description of a number of relevant parameters such as general text relation, marking for quotation, modification etc. If a systematic parameter analysis precedes discussions of possible correlations and the naming of features bundles as composite categories, a dynamic approach to categorization emerges which does justice to the varied and complex phenomena in this field. The database is the HyperHamlet corpus, a chronologically and generically wide-ranging collection of Hamlet references that confront linguistic and literary researchers with a comprehensive range of formal and stylistic issues. Its multi-dimensional encodings and search facilities provide the indispensable 'freedom from the analytic limits of hardcopy', as Jerome McGann put it. The methodological and heuristic gains include a more complete description of possible parameter settings, a clearer recognition of multiple

Correspondence:

Regula Hohl Trillini,

Kembserweg 21,

CH-4055 Basel,

Switzerland.

E-mail: r.hohl@unibas.ch parameter settings (as implicit in existing genre definitions), a better understanding of how parameters interact, descriptions of disregarded literary phenomena that feature unusual parameter combinations and, finally, descriptive labels for the most polysemous areas that may clarify matters without increasing taxonomical excess.

\section{Introduction: From Taxonomy to Parameters for Annotation}

Intertextuality is usually either theorized as an ontological concept or investigated through textdescriptive analysis, and the 'radical' and 'moderate' camps have remained fairly distinct. However, researchers who abandon universal, arbitrary, and 'always-already' signification for the study of relations between actual texts do not always limit themselves to enumerative description. They establish general categories and name them, coin GraecoLatinate neologisms, and re-define and re-apply technical terms and everyday vocabulary to a point where it is tempting to describe taxonomy as the besetting sin of intertextuality studies. This diversity reflects the complexity of intertextual processes, which have become a classic borderline phenomenon cutting across disciplines and paradigms, 'taken up in highly diverse fields and schools 
of thought, covered by confusing terminology and functionalized in the most diverse ways' (Schahadat, 1995, 366, our translation). To map such processes comprehensively seems as impossible a task as the depressingly futile construction of a 'Key to All Mythologies', which the ageing scholar Edward Casaubon attempts in George Eliot's Middlemarch. Even a brilliantly successful analogous project, Gérard Genette's Palimpsests, has been accused of 'terminological scholasticism' (Plett, 1988, 294). But how else could the vast array of possibilities and tokens become manageable, how else could the field ever go beyond the particular, beyond the enumerative 'Shakespeare quotations in Goethe' kind of scholarship, than by establishing categories and naming them, endlessly?

Scholars have attempted to cope with the complexity and ubiquity of intertextual evidence mainly by selection. The material that is investigated may be reduced in quantity or by focussing on selected aspects, with data chosen for the best fit with pre-established categories. Examples are studies of references in quotation marks (Morawski, 1970), of 'the limiting case of literal quotation' (Jenny, 1982, 34), of fictional characters that migrate out of their books (Müller, 1991), book titles explicitly mentioned in a novel (Hebel, 1989), marking strategies (Helbig, 1996), the phenomenon of wholesale re-writing, and of quotation strategies in single, richly allusive texts (countless examples). Such research, which pre-selects particular kinds of intertextual material and disregards others in order to formalize structural properties, can yield valid insights about manageable sets of data, about individual texts, genres or authors.

Discussing selected or individual texts is a privilege that literary studies have over linguistics, which prize statistical validity more highly. However, many publications with a limited database nevertheless aim to redefine or create generally applicable technical terms. Time and again, existing terms are contested, (re-)defined, and re-appropriated, and new words are created for only-just-established aspects. When this is done with reference to a limited body of material or with a narrow formal focus, the emerging terminological systems can cover only a small part of possible structures and the result is not an inclusive, widely applicable grid but a bewilderingly interferential taxonomical field. Peter Stocker, for example, systematizes intertextuality with regard to the general relation between two texts and the difference between references to genre and references to an individual text. He proposes six terms defined by a matrix (Stocker, 1998, 69):

\begin{tabular}{|c|c|c|c|}
\hline Mode Material & Quote & Thematize & Imitate \\
\hline Single text & $\begin{array}{l}\text { Palintextuality } \\
\quad[\text { intertextuality] }\end{array}$ & Metatextuality & Hypertextuality \\
\hline Class of texts & Demotextuality & Thematextuality & Similtextuality \\
\hline Material Mode & Demonstrate & Thematize & Imitate \\
\hline
\end{tabular}

This grid is problematic in several respects. The 2D matrix approach creates equally importantlooking names for phenomena of very different weight and practical importance: 'demotextuality', the self-referential and 'demonstrative' reproduction of literary genres (Stocker 1998, 68), is here on a par with 'hypertextuality', i.e. literary adaptation, but also with the widespread and hugely diverse phenomena of localized quotation (also called reference or allusion). Since the more current term 'intertextuality' is its own hyponym here, the neologism 'palintextuality' is created. When Stocker finally comments that cases of 'demotextuality' and 'similtextuality' (further neologisms) might be rather hard to distinguish in certain cases (Stocker 1998, 70), it becomes clear that attempts to cure terminological confusion by further naming are likely merely to make the general vulnerability of category systems more obvious.

To coin terms through 2D matrixes is of limited use also because the intertextual process has so many aspects. The term allusion, for example, has been defined many times, in opposition to different things, and with a varying degree of overlap in the choice of defining aspects. Perri (1978) and Lennon (2004) define the associative meaning deriving from the earlier text as allusion's distinctive property, whereas quotations merely mention a certain passage. Meyer 1968, on the other hand, uses quotation only where the recognition of the earlier text is 
necessary for the meaning construction of the later text; otherwise, he speaks of 'borrowings'. For Holthuis, thirdly, allusions are 'non-linearized properties or text features' and quotations are 'linearized textual elements' (Holthuis, 1994, 80), while Michael Wheeler speaks of 'quotations and references, the two basic types of allusion' (Wheeler, $1979,1)$. This is confusing.

Given that not even 'main types' can be clearly distinguished because relations in their abundance are 'hardly distinguishable nor practicable' (Heinemann, 1997, 35 ${ }^{1}$ ), eclectic naming which does not take account of the importance and frequency of categorized phenomena will not further scholarly communication. The danger is also that dimensions and phenomena which are relevant and flourishing in textual practice may be disregarded because the theoretical matrices cannot account for them. Therefore, we suggest that what should be reduced is not the number of materials and dimensions under discussion but the number of categories that are established and named, and rather than suggest further new terms, we propose a model which enforces cognizance of a wider range of existing phenomena. Instead of pondering contested terms such as 'allusion' only to define them yet again, it offers a methodology for implementing (through a database) a more dynamic approach to the complex literary and linguistic phenomena of intertextual reference. The aim is to formalize basic intertextual phenomena in a structurally inclusive yet operationalized way, which also takes account of large amounts of materials that have not been pre-selected to fit a given focus of interest. How can this be done?

The proposed model is based on a collaboration between literary scholars and linguists, which confirmed our conviction that, in the field of intertextuality, the former sister disciplines of 'lit' and 'lang' can learn a lot from each other. Intertextuality has too many aspects which elude 'simple' syntactic or morphological analysis to be left to linguists, and too many aspects which are only graspable through such analysis to be left to literary scholars. Therefore, the model includes pertinent research paradigms from both disciplines, taking inspiration from poststructuralist theory as well as electronic research media and from the hard sciences' way of tackling taxonomy issues in order to propose two changes which may point a way forward.

First, a data-driven approach avoids overtheorizing because it bases analysis on the inductive study of a critical mass of data. These very terms are untypical for the usual approach of literary studies, but the concept also avoids the limitations of those linguistic publications which pre-select tokens for availability and manageableness. Including texts and aspects that may slip through the net of preconceived categories, it offers results that are plausible beyond individual analyses. As regards genre, this inclusiveness (ranging from literary works through popular culture and non-fiction of all kinds) is essential both to linguistics and to the Cultural Studies school of literary studies.

Secondly, the intertextual phenomena that can be observed in this body of material are analysed forliterally 'resolved into'-separate parameters. ${ }^{2}$ These parameters (dimensions, features, aspects) are not combined in static matrixes which demand names for every possible combination, but are first observed and discussed independently of each other. This leads to a more precise yet inclusive outlook, with an essentially descriptive focus as a basis for later work. Rather than add to what should really be called 'taxology' (ordering by name-giving), we propose to act out the literal meaning of 'taxonomy' by suggesting 'laws for ordering'. This careful isolation of features should enable more effective communication between students of intertextuality from various disciplines by avoiding naming of near-empty categories, clarifying over-named areas and highlighting not-yet-named phenomena. Once a critical mass of data are analysed for independent parameters without a bias towards traditional categories, correlations in the form of recurrent combinations of parameter settings may emerge which do justify new names or enable new definitions of familiar terms. But this goal must not be approached hastily. It is essential to start by a stringent analysis of data, which does not anticipate complex categories.

If categories are thus open to definition, as bundles of features or parameter settings, a dynamic approach to terminology becomes possible which 
does not see taxonomy as a mirror of a static truth, but as a tool for specific research approaches. A focus on annotating single features or parameters rather than on assigning texts to certain categories allows us to study texts unencumbered by a need for naming and rigorous definition, to include aspects which have been obscured by data selection or a highly specific focus and to systematize them in a way that may make further research more sophisticated. Furthermore, this dynamic approach ties in with the concept of meaning construction of the cognitive sciences: meaning-including the meaning of technical terms - is not a fixed value but a 'dynamic solution to a range of specific problems' (Wray, 2002, 4, 59). The model refers, of course, to previously published research but aims not to take established categories for granted. True to the aim of deferring further additions to taxonomy, both parameters and parameter settings are labelled, as far as possible, by transparent descriptions that avoid the most disputed terms and can be understood across disciplinary boundaries. Thus published observations can be made use of regardless of whether their terminology has had any follow-up.

\section{Parameters of Intertextuality I: Elements and Relations}

Intertextual processes involve, minimally, an earlier and a later text and an element from the former that is discernible in the latter. Various terms have suggested for these simple givens. Plett 1988, for example, refers to the later text as 'target text' and numbers it 'T1'. This expresses a literary critic's preoccupation with an allusive work of art which takes priority over its sources or 'pre-texts', but is counterintuitive with regard to the temporal structure of the intertextual process, 'T2' being the name for earlier text. Gérard Genette's 'hypotext' (earlier) and 'hypertext' (later) use a spatial metaphor and Wheeler's 'adopted' (earlier) and 'adoptive' (later) text a familial one (Wheeler, 1979, 2). Other proposed terms for the earlier text include 'Referenztext' (Lachmann, 1984) and 'original discourse' or 'unit of language in absentia' (Lennon, 2004), which are contrasted with 'Phänotext', 'quoting discourse' and 'unit of language in presentia', respectively. The process itself has been referred to, for example, as 'transplanting' and 'framing' (Sternberg, 1982), 'shift of mental sets' (Tsur, 1998) or 'representing discourse within discourse' (Scollon, 2004). As these selected examples show, intertextuality terminology is abundant even at the most basic level, ${ }^{3}$ and there is no general agreement on what the significant aspects of the relationship between two texts are. For a formal parameter analysis, we posit the following three questions as elementary:

What does the later text do with the earlier text? Which elements from the earlier text are discernible in the later text?

Which function(s) do these elements assume in the later text?

These questions represent the three basic parameters of the model (rendered in CAPITALs from now on): Relation Type, ${ }^{4}$ Quoted Element und Function. They are not always neatly separated in published research; as will be seen, both current and obscure terms frequently include information about two or three of these parameters (and sometimes others). In contrast, a thorough parameter-by-parameter consideration may sharpen perceptions of the material described by these labels and draw attention to phenomena not covered by them.

\subsection{Relation type: what does the later text do with the earlier text?}

The exact quality of intertextual ReLATIONs has interested mostly literary scholars, especially famously Gérard Genette, who proposed highly successful terms for relationships between texts in Palimpsests (1982). Intertextuality refers to those local references covered by traditional terms such as quotation and allusion; hypertextuality describes literary adaptations which replicate an earlier work's plot, and architextuality describes genre as an intertextual notion, reading the genre of any text as a reference 
to a body of earlier texts in the same genre. ${ }^{5}$ Finally, metatextuality is Genette's term for texts about other texts. These definitions have re-appeared (occasionally under different names) in most research since Palimpsests, not excluding the present study. However, they have not gone completely unchallenged, and the model suggested here, while basing its parameter Relation Type on Genette, offers the possibility to confront two important objections and suggests how they could be met to improve the heuristic potential of Genette's these categories. First, more than just one setting should be available for any single intertextual reference, and secondly, three of Genette's terms should not be seen as essentially different but (more usefully) as representing a single type of intertextual relation which is further differentiated by other parameters.

First, multiple settings for one parameter. Genette's model assigns one single Relation Type to every text which refers to another, roughly corresponding to the genre of the later text: metatextuality is typical of literary criticism, hypertextuality occurs exclusively in fictional texts etc. While it is undeniable that most texts exhibit a dominant type of intertextuality ReLATION TyPe, it is reductive to ignore the possibility of multiple types. In her discussion of Tom Stoppard's 1967 Rosencrantz and Guildenstern are Dead, Thaïs Morgan observes that this play 'quotes [Hamlet] (intertextuality), criticizes [its] theses (metatextuality), and borrows [its] genetic structure (hypertextuality)' (Morgan, $1985,31)$. She concludes that to assign a single category to such a text may be 'a giant step forwardin taxonomy' but also represents 'a giant step backward-in interpretation-for the semiotics of intertextuality' (33).

It could be objected that an idiosyncratic literary work like Rosencrantz and Guildenstern does not justify the upsetting of an extremely useful and influential set of categories. However, multiple RELATION TyPes occur also outside postmodern literature, and even outside fiction. Fictional characters in novels may have conversations about Shakespeare plays, and conversely, nonfictional texts may quote them. Gary Taylor's Cultural History of Shakespeare, for example, contains the following sentence about the French Revolution: 'The French acted the tragedy; the English watched, exercised (or exorcised) their pity and fear, moralized upon the spectacle and then-to quote Hamlet-"did nothing"' (101). While the larger scheme of Taylor's book is metatextual (he discusses Shakespeare's works), Taylor does not make reference to the wider implications of the Hamlet plot in this particular passage, but integrates Hamlet's language into his own text for richness and weight as any novelist or journalist might. These and countless other examples show that Morgan's indictment of the narrowing of vision which Genette's strict taxonomy entails is very apt indeed although it has not been systematically followed up.

As a second improvement on Genette's system, we suggest to avoid the strict separation of interand hypertextuality or quotation and adaptation or imitation which Genette's followers have adopted. The two are not really mutually exclusive opposites but belong to a continuum which includes phenomena of extremely varied degrees of intensity or extensiveness, possibly even Genette's architextuality. We suggest the term integration for texts which occupy this continuum, texts, which, in Peter Stocker's words, speak 'through' ('mit') the words of another text (Stocker, 1998, 55). Instances of intertextual integration range from a single mention of Hamlet like the one by Gary Taylor just mentioned, through works that do not replicate Shakespeare's plot but are interspersed with Hamlet references (such as Thomas Mann's 'Tonio Kröger' or Chapter 9 of Joyce's Ulysses), to dramatic adaptations and offshoots like Alethea Hayter's 1972 novel Horatio's Version, which describes a police investigation following Hamlet's death. Shakespeare's text and its characters are integral parts of the language of the texts in which they feature, or-in the cases of Hayter and Stoppard-part of their fictional universe. Hamlet is not only discussed as an external phenomenon (as it is indeed by Taylor's academic voice and by Mann's and Joyce'sthough not Stoppard's-characters), but integrated into the language of a monograph, the symbolic system of a novella or the plot fabric of a play. 
To fragment the discussion of such works into separate consideration of intertextual, hypertextual and architextual works is reductive and unsatisfactory. The differences between these terms are more usefully accounted for by considering further parameters, as will be discussed below.

Considering all this, the proposed model distinguishes the following parameter settings or TYPES of intertextual RELATION:

ReLATION Types between earlier and later text

(Element from) earlier text integrated into later text (Element from) earlier text discussed in later text (Element from) earlier text translated by later text (Element from) earlier text listed in later text (Element from) earlier text set to music by later 'text' (Element from) earlier text illustrated by later 'text'

Most of these Relation Types can be related to certain genres such as translation, anthology, sculpture or lied, in which they tend to be dominant; but they, too may occur in combination. A French anthology of quotations, for example, which contains the phrase 'être ou ne pas être', both translates and lists this short extract, while Wolfgang Rihm's opera Hamletmaschine involves translation and setting to music but also integration of many different linguistic items ${ }^{6}$ and plot elements from Hamlet. Many other combinations can be found and usefully conceptualized if indeed every text can be assigned multiple ReLation TYPEs.

On the other hand, as has been mentioned, the diversity of phenomena in those many texts that we subsume under integration (including Genette's intertextuality, architextuality, and hypertextuality) cannot be fully accounted for even by multiple Relation Types. For a more satisfactory analysis, we suggest differentiation according to the elements from the earlier text that reappear in the later text. For the sake of concision, these will be called Quoted Elements from now on, using the term 'quote' in the loosest possible sense which specifies nothing beyond recognizable re-occurrence. What these elements are and what they become as they are 'quoted' are the two parameters that need to be considered next.

\subsection{Quoted elements and their function in the later text}

In a discussion of what is 'quoted', the fundamental distinction is between references with a surface match that can be traced to a particular passage, and references to elements that cannot be localized because they are implicit or recur throughout, such as names, plot elements or genre. Simple correlations between earlier and later text constitute straightforward cases which would be adequately served by terms like hypertextuality, intertextuality, architextuality or translation: plot becomes plot, isolated phrase becomes isolated phrase, genre determines genre, English text becomes French text. However, there are many texts which go beyond such one-to-one correlations. These have not hitherto been very well served by formal analyses. Steven Berkoff's poem cycle The Secret Love Life of Ophelia, for example, features many different kinds of integration (whereas discussion or translation are absent): it contains quotations from Hamlet, but also borrows the plot strand concerning the relationship between Hamlet and Ophelia (under their original names) in a sequence of verse letters which integrate short extracts from Shakespeare's play, and ends with a description of Ophelia's death lifted entirely from Hamlet. Again, multiple parameter assignment is of the essence to account for so many Quoted Elements and their new Functions, and again, Berkoff's text is not a singular case. Novels may use a Hamlet phrase as their title and extend Shakespeare's plot with figures that bear related names, or may be interspersed with Hamlet quotations because their characters discuss or perform the play and may or may not resemble Shakespeare's characters. In this way, Quoted Elements and Relation Types complement each other, or, as Allison Wray puts it: taxonomic 'cross-associations [...] of subsets are probably nearer to the truth than single-parameter categorization' (Wray, 2002, 48). 
Our model distinguishes the following Quoted ELEMENTS, mirrored by the Functions which they may assume in the later text:

\section{Quoted ELEMENT and FunCtion Verbal \\ Phrase $^{7}$ \\ Longer passage \\ Complete text \\ Recurring phrases \\ Thematic \\ Motif or plot element \\ Plot (complete) \\ Genre \\ Nominal \\ Title \\ Name (place or character)}

The settings of Function correspond exactly to those of Quoted ELEMENT: both represent the formal, thematic and nominal (or onomastic) constituents of a text, and both correlate closely though not exclusively with certain ReLATION TyPEs; translations, musical settings of texts, and paintings which represent a fictional character usually correspond in their entirety to (a part of) the earlier text which they map, while anthologies (Relation Type listed) typically feature shorter phrases or passages. Published research provides a plethora of terms for these phenomena, but as will be shown (see Table 1), these are often mutually incompatible because they assume particular Relation Types, do not systematically separate Quoted Element and Function, or imply further distinctions such as the question of the attitude (e.g. serious or parodying) of the later text. ${ }^{8}$ The following table lists some terms suggested in published research and shows the complex interaction of the proposed (and additional) parameters which is implicit in these terms.

Table 1 evidences the difficulty of representing the complexity of intertextual relationships in print. It combines just the three basic parameters with their several settings and moreover simplifies Relation Type by giving just the dominant type for each genre rather than showing multiple settings; nor does it distinguish whether certain Relation Types are optional or defining for a conventional genre term. And yet this simplified matrix is desperately unwieldy. Nevertheless, some of its features visualize the terminological issues of intertextuality in a useful way. The shaded matrix boxes highlight the excess of naming which intertextuality studies have lavished on certain distinctions. Conversely, the completely empty boxes show up phenomena for which textlinguistic terminology is ahead of conventional or purely literary perception, which offers no terms for them, and others which have been suffering from a comparative terminological neglect although the relevant artefacts (e.g. Hamlet operas) have been analysed individually. Thirdly, the table draws our attention to phenomena for which neither traditional literary studies nor intertextual analysis offer any terms at all, so that only descriptions (in italics) are possible.

\section{Parameters of Intertextuality II: The Elements Affected}

Beyond the minimum of two texts, the elements that travel between them and the relations which these elements constitute between the texts, the model must account for how the quoted element and the later text are affected by the intertextual process. How (if at all) is the Quoted ElEmenT modified in the later text and how (if at all) does the later text signal the presence of an extraneous element? For these two parameters, the terminological situation is less desperate. Modification and MARKING are comparatively independent from each other and from the three basic elements outlined above, and they have been isolated more neatly in published research. However, such research has tended to focus on the obvious. Humorous kinds of Modification ('2B or not $2 \mathrm{~B}$ ') or MARKING in the form of quotation marks are well researched, while less explicit (and more sophisticated) kinds of phenomena have often remained below the radar of researchers with a systematic bent. Therefore, it is not so much confusion as incompleteness that needs to be 


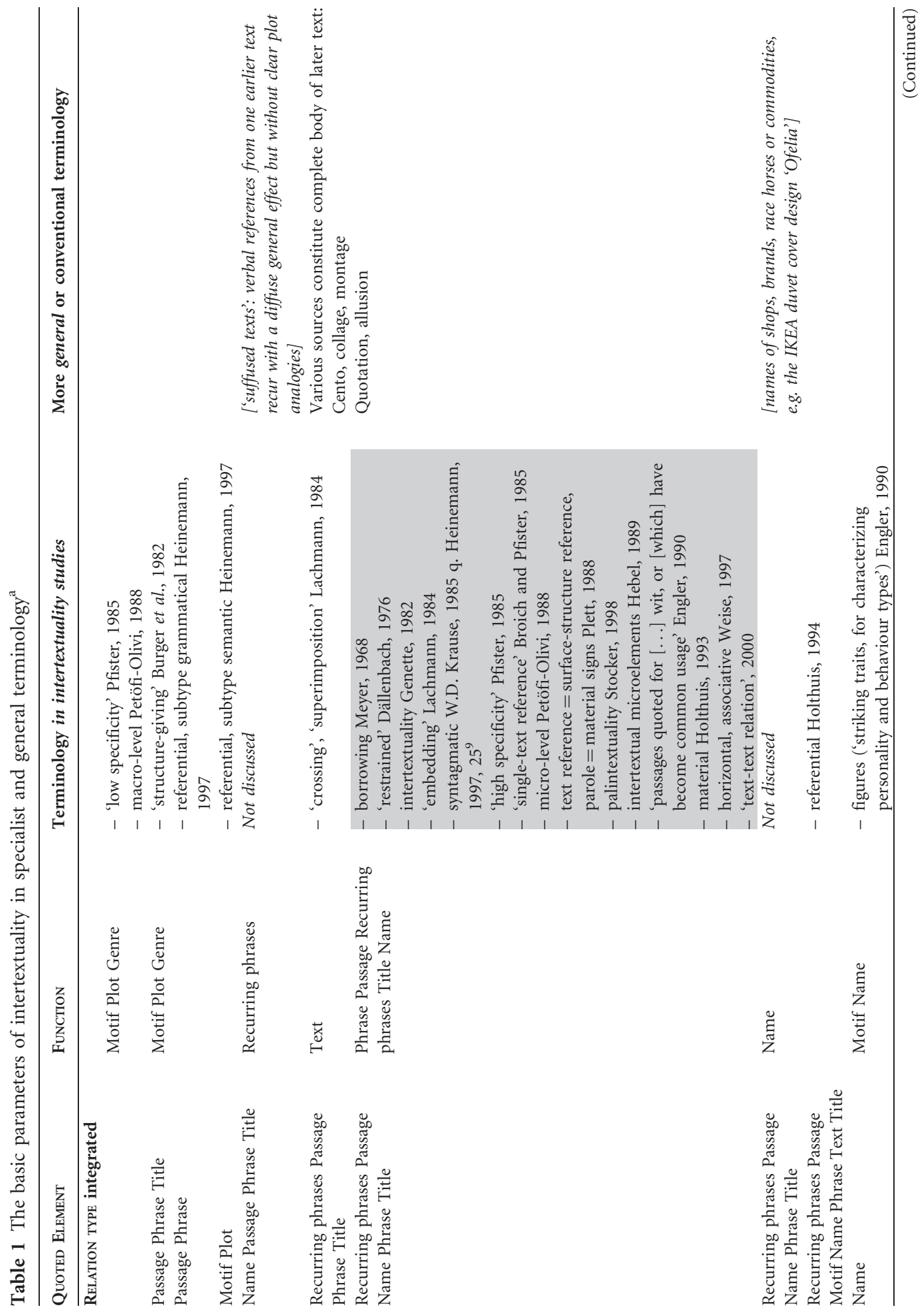

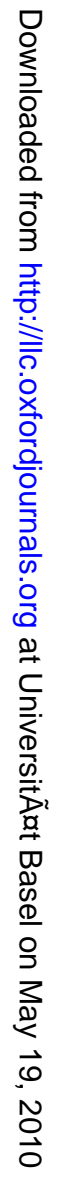

8 of 18 Literary and Linguistic Computing, 2010 


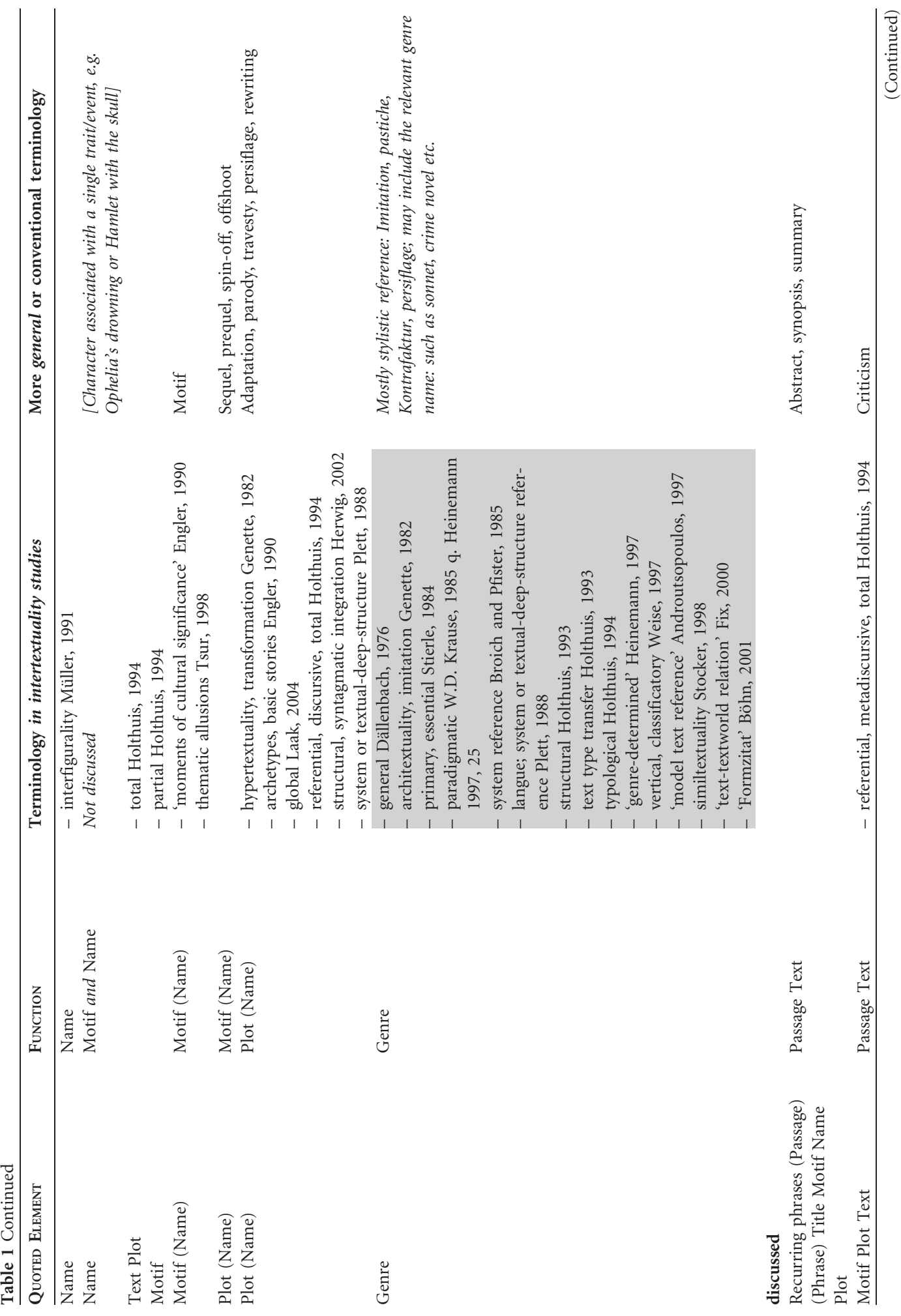




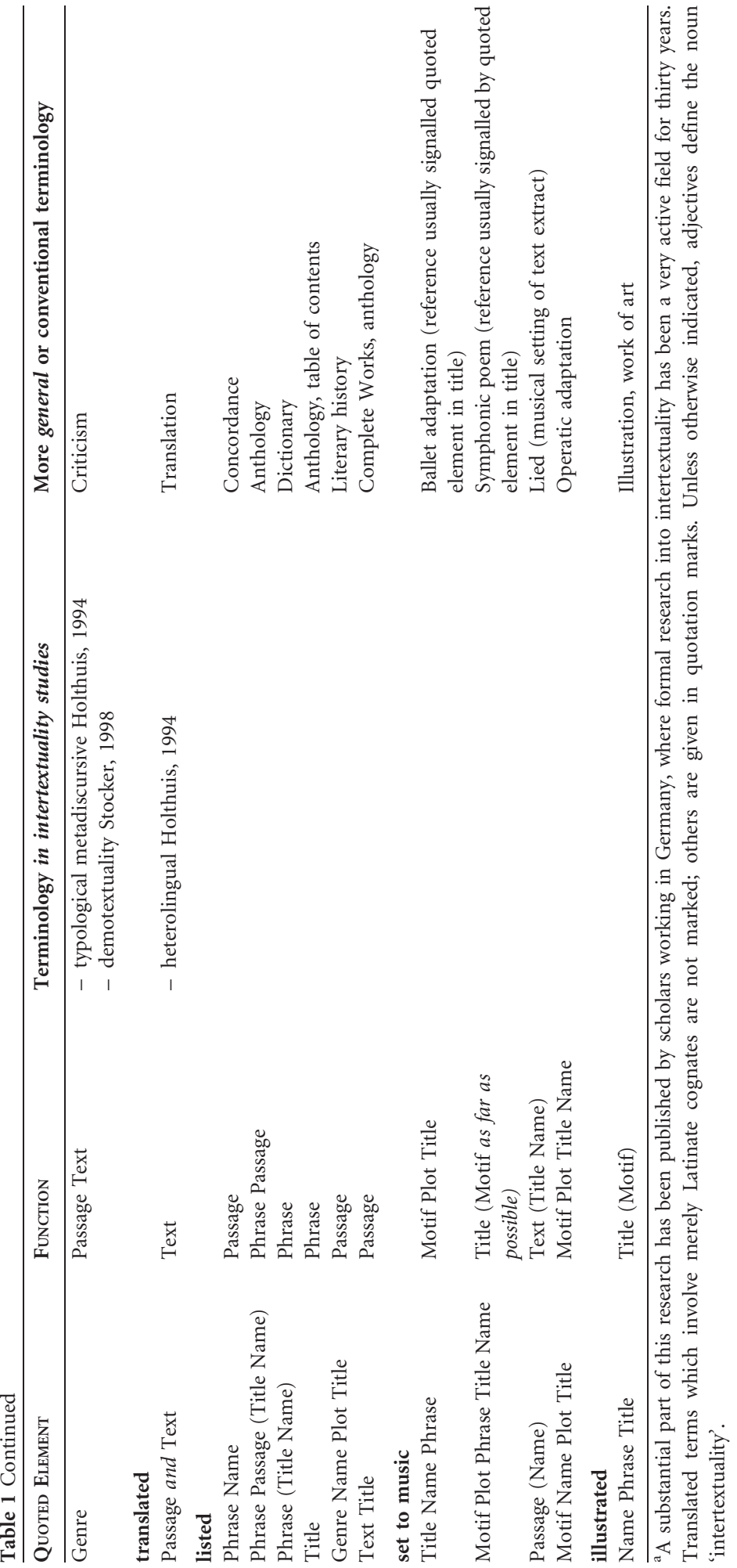

10 of 18 Literary and Linguistic Computing, 2010 
addressed for systematic and operational parameter descriptions.

\subsection{Modification}

In the case of Modification, i.e. the 'relation of assimilated utterances to their initial state' (Jenny, $1982,50)$, description can partly rely on established terms from outside the contested field of intertextuality, as described in classic treatises on rhetoric and grammar: addition, omission, substitution and permutation. For single phrases and passages, this can seem so straightforward that this parameter has even been used to distinguish the contested terms of quotation-exhibiting fewer and less extensive Modification processes-from allusion and 'paraphrase', which are so thoroughly transformative 'that their reference to a pre-text is primarily semantic' (Plett, 1988, 197). However, for a useful analysis, the size of the quoted element, i.e. the extent of the earlier and later text, must be included. A simple re-occurrence of identical items would be easy to operationalize, but this narrow definition cannot account for processes like substitution and addition. In fact, semantic as well as structural criteria $^{10}$ have to be considered. In the proposed model, this is delineated in terms of syntactic phrase structure.

\subsection{Marking}

Research on MARKING has been dominated by two reductive tendencies: the focus on overtly marked intertextual references mentioned above, and a preoccupation with authorial intention. The two are partly related: while a concentration on evident material may have 'heuristic reasons' (Grüttemeier, $2000,129^{11}$ ), limiting enquiries to cases of 'flagrant quotation' which are 'isolated and proclaimed by typographical devices' (Lewis, 1969, 134) or to overt anomalies ${ }^{12}$ enables researchers to be confident about 'a reader-response narrowly controlled by the text' (Riffaterre, 1994, 787-8) and the author's planning of such control. ${ }^{13}$ Specific concepts of intertextuality which are motivated by an interest in such control fail, however, to account for important phenomena. Literary texts may contain 'embedded [...] sentences or phrases [...] artfully worked into an author's own language so that an ignorant reader might not recognize them' (Lewis, $1969,134)$, so that the unobtrusiveness of quotation does not necessarily signify lack of authorial intention or awareness. A focus on overt marking also fails to account for those quoted phrases which have become idiomatic or proverbial through frequent re-quotation and are used 'with no sense of quotation' (Lewis, 1969, 135). Excluding such instances deprives our vision of intertextual semiosis of 'those properties of the text [...] which were not given to it intentionally. These may include unconscious elements of authors' cultural knowledge and the way in which they are determined by discursive formations of his time' (Herwig, 2002, 170, our translation $\left.^{14}\right)$. Readers may perceive relationships to earlier texts, contemporaneous texts, and even later texts and use them for semiosis, relationships that were not intended or could not even have been intended because of the time of their composition, but may nevertheless be culturally significant.

What Balz Engler says about readers' recognition of intertextual reference obviously also applies to authorial intention: neither can be taken for granted, but 'whatever the [...] link with the source, the use of such phrases will tell us something about the role authors and their work play in the culture' (Engler, 2003). Laurent Stern argues in a similar vein that '[a]uthors may have privileged or inside information about what they want to say' (Stern, 1980, 123), but what they betray through the subconscious use of conventions, clichés, or omissions is manifest and accessible in the text itself. This stance resembles that of Julia Kristeva, who claims that the 'notion of intertextuality replaces that of intersubjectivity' (Kristeva, 1967, 441, our translation ${ }^{15}$ ) and for whom, therefore, the question of 'whether an author knew a certain text, whether he consciously and intentionally refers to it and whether he presupposes in the reader both knowledge of the pretext and the ability to recognize a recourse to it' (Herwig, 2002, 169 ${ }^{16}$ ) becomes irrelevant. We concur with this methodologically: The model does not deny authorial intention or the possibility of descrying it, but we suggest that any comments on this issue should be deferred until a more comprehensive analysis of both overt and non-overt formal 
phenomena has been established. Such a descriptive model which aims at inclusiveness must consider also those items which are not overt enough to provide conclusive evidence of authorial intention. In fact, everything that can be perceived as evidence of intertextual reference must be discussed in order to encompass the widest possible range of phenomena and provide a valid database for later research.

The parameter description as used in the suggested model charts the following observable textlinguistic features that are related to the issue of MARKING.

MARKING FOR QUOTATION

(1) Textually explicit: distinct name

(2) Textually explicit: verbum dicendi or other metalinguistic marking

(3) Typographical (quotation marks, italics,

(4) Textually implicit: syntactical anomaly, register mix, anachronism etc.

(5) Genre (e.g. anthology)

(6) Context

(7) Not marked

Particularly interesting items in this list are Marking by genre and Marking by name. The occurrence of any name (of a literary work, one of its characters or the author) signals an extraneous point of reference and is thus part of the system that marks intertextuality, not only in stereotyped formulae such as 'cf. Hamlet, act 5'. We suggest to consider any mention of the author separately from footnotes etc.)

the occurrence of any kind of place or character name from the earlier text (see the outline given in Quassdorf and Hohl Trillini, 2008). The examples assume Shakespeare's Hamlet as the earlier text.

The NAme markings (AUTHOR and Work) can occur independently of each other and of other forms of MARKING FOR QUOTATION, with varying effects. Co-occurrences may disambiguate potentially polyfunctional markers such as quotation marks or grammatical anomalies, while the absence or presence of markers for author and work are relevant to research on the continued power of Shakespeare or Hamlet, respectively, as cultural icons.

\section{Implementing the Model}

\subsection{A multidimensionally annotated electronic corpus}

The difficulties of displaying a multi-dimensional system of independent but interactive parameters in print have been mentioned and demonstrated. As happens increasingly in the hard sciences, this corpus-based parameter model for the study of intertextuality relies on an electronic database. Electronic data management can handle complex, multi-dimensional definition matrixes, and allows researchers to choose their categories dynamically according to interest and research perspective; in fact, it makes a qualitative difference by providing 'freedom from the analytic limits of hardcopy' (McGann, no pagination).

The electronic prototype for the model is the HyperHamlet database developed at the University of Basel (accessible at http://www.hyperhamlet. unibas.ch). It takes the shape of a hypertext of

NAME: MARKING FOR WORK

NAME: MARKING FOR AUTHOR

(1) Title (Hamlet)

(2) Epithet (the greatest English tragedy)

(3) Anonymous work (that famous book)

(4) No work (the well-known saying)

(5) Incorrectly attributed (Macbeth, the Bible)

(6) Context $^{17}$

(7) Character name(s)

(8) Not marked 
Shakespeare's Hamlet in which every line can provide access to texts and artefacts which refer to it in some way. Thus a critical mass of data from a variety of sources and genres is gained by inverting the usual procedure of intertextual research. Turning upside down what might be called the 'sources paradigm', our taxonomic work is not based on the references contained within a single later text, author or genre (which inevitably provide a stylistically limited range of phenomena even if they are most prolifically allusive), but on the thousands of texts that refer to one famous work in many different ways. Hamlet (and phrases and motifs from it) is so popular in English and in other languages that the database records more than 8,000 selected references from literary and non-literary sources dating from 1600 to 2010. All these data are annotated for the parameters described above, and can be searched for them separately or in combination. $^{18}$ As mentioned above, the possibility to conduct complex searches enables users to defer naming and handle categories dynamically as feature combinations. This openness coincides with the convergence of poststructuralist literary theory and hypertext technology as described by George P. Landow, who sees the 'ideal textuality' envisaged by Roland Barthes as an exact match of computer hypertext: 'text composed of blocks of words or images linked electronically be multiple paths, chains or trails in an open-ended perpetually unfinished textuality described by the terms link, node, network, web, and path' (Landow, 2006, 2).

\subsection{Towards full annotation}

In addition to Marking and Modification, which describe the effects of the intertextual process on its basic components, an open-ended number of further parameters can be defined which are not essential to the model but nevertheless of practical relevance to a database with the format described here. Some possible parameters that might benefit various projects:

LANGUAGE enables searches for particular national or linguistic contexts.

GenRe is a notoriously complex issue, but also one of the few generalizations which are both admissible in literary studies and accepted by linguists.
The HyperHamlet database offers a selection of conventional terms grouped under Fiction, NonFiction, and Other. These terms, too, could be defined as combinations of parameter settings such as Medium, Language mode (prose, verse or other), Subject, Speech Act, Target Audience etc., but-apart from the limits of practicability-the interesting correlations between genre and intertextual processes, which do exist, are not general enough for such analytic parameters to add defining insights.

An Author is assigned to all later texts in the corpus, which enables literary scholars to study the intertextual habits of individuals or groups.

DATE is important for all historical projects and for linguists who want to isolate synchronous data sets. Splitting this parameter between DATE OF Composition and Date of First Publication distinguishes two significant moments: (1) when a reaction to the earlier text happens and (2) when this re-usage enters the public realm and becomes itself available for re-quotation. The interval between the two may be very small, as in letters and oral communication, but can be considerable and worth recording in the case of works with an extended gestation period or for genres such as diaries.

Indicating the FunCTION of a quoted element in the later text is useful to researchers who are interested in materials which either integrate the quoted element into the body of a text or, conversely, in quoted elements which are used as book titles, epigraphs or other paratexts. Narrative Voice indicates whether a passage in a fictional text represents dialogue or a first- or third-person narrator.

All these parameters describe the later, quoting text. Mirroring options are of course also possible but not all of them would be quite as interesting. Analyzing the Narrative Voice which a quoted element has IN THE EARLIER TEXT, for example, allows research into the intertextual fruitfulness of particular elements in the earlier text, answering questions such as: 'Have utterances in direct speech or extracts from the narrative voice proved particularly memorable?' If the quoted text is, like Hamlet, a play, this differentiation may seem trivial; it is nevertheless interesting to see that certain stage directions in their exact wording (which are never 
heard in performance) have become quotable as Shakespeare's plays turn into reading texts, for example in the title of Philip Roth's 2007 novel Exit Ghost.

\section{Conclusion: Methodological and Heuristic Gains}

The methodological and heuristic gains from the proposed model of studying parameters of the intertextual process in isolation and with an inclusive database can be grouped under three headings.

First, the closer attention to the parameters of the intertextual process that comes with analyzing and operationalizing them independently allows a more nearly exhaustive account of the possible settings of every individual parameter, as has been shown.

Secondly, a clear understanding of the workings of every individual parameter makes it possible to recognize multiple parameter settings more clearly and to avoid overlapping or portmanteau categories in many contexts. The advantage of multiple Relation Types has been mentioned above as a means of improving on Gérard Genette's categories, and a differentiated look at intertextual phenomena which consideration of multiple QuOTED ELEMENTS and Functions makes possible is set out in the table above. MARKInG is a further case in point: the majority of quotations which involve MARKING combine at least two such elements; Quassdorf and Hohl Trillini, 2008 discusses diffuse and multiple forms of marking, both implicit and explicit, as well as the polyfunctionality of quotation marks. An even more inclusive analysis of ways of MARKING FOR QUOTATION may allow insights into the degree of lexicalization of phraseological units that are derived from a literary text. The complete absence of marking (including archaisms and syntactical irregularities) or the isolated occurrence of MARKING for a collective author are necessary but not sufficient preconditions for inferring that elements such as primrose path or speak daggers have become lexicalized and lost the memory of their origin in Hamlet for the majority of users.
Thirdly, the separation of parameters is a precondition for understanding how parameters interact. This, too, can be illustrated through the issue of lexicalization. In combination with MARKING for a collective (or no) author, obvious Modification may indicate the unselfconscious use of an element and thus familiarity (see Langlotz, 2006 on idiomatic creativity), both of which are possible indicators of lexicalization. Another example, more germane to literary studies, is the (hitherto neglected) discussion of how adaptations and offshoots are marked for their origin, i.e. how FunCTION and MARKING interact in cases of integration. Apart from titles like Hamlet Travesty, how are Genettian hypertexts identified as such? Joyce's Ulysses, which signals its central earlier text in nothing but its title, remains the most famous example, but there is also Jane Smiley's novel A Thousand Acres (1991), which reenacts the plot of King Lear among Iowa farmers with absolutely no formal markers except for the initials of some protagonists' names. Other rewritings include names, verbatim quotations or strategies of self-reflexivity involving genre. A discussion of all these cases will be more useful if the individual uses and combined effects of MARKING, Modification and Function etc. are considered without the bias of traditional literary genre designations.

Thus, a clear analysis of parameter interaction will elucidate disregarded literary phenomena that have gone unresearched because they do not fit into easy-to-manage taxonomical categories. Several slots in the table above are overcrowded, while others are empty, alerting us to parameter combinations that may raise new research questions or invite a more systematic discussion of phenomena for which there are no conventional terms available. Such phenomena include what we have come to think of as 'suffused' texts (shot through with recurrent references to another work), quotations that are used as names or the distribution and frequency of certain passages in quotation dictionaries and anthologies as indicators of an author's or a work's cultural status.

Finally, a thorough application of parameter interaction may be used to suggest some clarification for those areas where the polysemy is most 
confusing. A case in point is the term quotation (which has been mentioned before), where scholars have stressed highly diverse aspects and criteria as points of departure: typographical or prosodic marking, attribution to a certain source, metarepresentative qualities, echoic or repetitive properties, not to mention classical syntactic, semantic or pragmatic criteria. If one or more of these approaches are not chosen consciously and applied adequately, confusion and misunderstanding rather than fruitful cross-over findings will ensue. Descriptive labels for certain combinations of parameter settings - bundles of features - could help to clarify matters without further exacerbating taxonomical excess.

Edward Casaubon's example in Middlemarch must serve as a warning that attempts to establish 'A Key to All' of any kind are doomed and may even be dangerous to those who undertake them, particularly since manifestations of intertextuality continue to proliferate in a way that pre-Christian mythologies do not. We must be careful to take a Key to All Quotations as a Utopian horizon rather than a reachable goal. The parameter model profits from the lesson of Middlemarch by acknowledging that the complexity of text relations cannot ultimately be mastered by definitions and by offering some progress through an explanation of the structural complexity which makes mastery impossible. In this way, we can hope to take further useful steps in handling some of the complex material we have undertaken to study.

\section{Acknowledgements}

We are profoundly grateful for the openmindedness and insight which Balz Engler and Annelies Häcki Buhofer brought to the stimulating cross-disciplinary discussions that made this article happen. John Lavagnino's comments further helped us to refine our conceptions. We also thank SonjaIrene Grieder for her careful proofreading.

\section{References}

Androutsopoulos, J. K. (1997). Intertextualität in jugendkulturellen Textsorten. In Klein, J. and Fix, U. (eds),
Textbeziehungen: Linguistische und literaturwissenschaftliche Beiträge zur Intertextualität. Tübingen: Stauffenburg, pp. 373-82.

Beaugrande, R. and Dressler, W. (1981). Einführung in die Textliguistik. Tübingen: Max Niemeyer.

Böhn, A. (2001). Das Formzitat: Bestimmung einer Textstrategie im Spannungsfeld zwischen Intertextualitätsforschung und Gattungstheorie. Berlin: Erich Schmidt.

Bolden, G. (2004). The Quote and Beyond: Defining Boundaries of Reported Speech in Conversational Russian. Journal of Pragmatics, 36: 1071-118.

Broich, U. (1985). Formen der Markierung von Intertextualität. In Broich, U. and Pfister, M. (eds), Intertextualität: Formen, Funktionen, anglistische Fallstudien. Niemeyer: Tübingen, pp. 31-47.

Burger, H., Buhofer, A., and Sialm, A. (1982). Handbuch der Phraseologie. Berlin, New York: Walter de Gruyter.

Dällenbach, L. (1976). Intertexte et autotexte. Poétique: revue de théorie et d'analyse littéraires, 27: 282-96.

Engler, B. (1990). Poetry and Community. Tübingen: Stauffenburg.

Engler, B. (2003). Constructing Shakespeares in Europe. In Hoenselaars, T. and Pujante, A.-L. (eds), Four Centuries of Shakespeare in Europe. Newark: University of Delaware Press.

Fix, U. (2000). Aspekte der Intertextualität. In Brinker, K. et al. (eds), Text- und Gesprächslinguistik: Ein internationales Handbuch zeitgenössischer Forschung. Berlin: Walter de Gruyter, pp. 449-57.

Genette, G. (1982). Palimpsestes: La littérature au second degré. Paris: Seuil.

Genette, G. (1997). C. Newman and C. Doubinsky (trans.), Palimpsests: Literature in the Second Degree. Lincoln: University of Nebraska Press.

Grüttemeier, R. (2000). Über Markierung, Zitat und Zitatbereich als literarhistorische Parameter: Am Beispiel der 'Nieuwe Zakelijkheid'. In Beekman, K. and Grüttemeier, R. (eds), Instrument Zitat: Über den literarhistorischen und institutionellen Nutzen von Zitaten und Zitieren. Amsterdam: Rodopi, pp. 133-64.

Hebel, U. J. (1989). Romaninterpretation als Textarchäologie: Untersuchungen zur Intertextualität am Beispiel von F. Scott Fitzgeralds This Side of Paradise. Frankfurt: Peter Lang.

Heinemann, W. (1997). Zur Eingrenzung des Intertextualitätsbegriffs aus textlinguistischer Sicht. 
In Klein, J. and Fix, U. (eds), Textbeziehungen: Linguistische und literaturwissenschaftliche Beiträge zur Intertextualität. Tübingen: Stauffenburg, pp. 21-37.

Helbig, J. (1996). Intertextualität und Markierung: Untersuchungen zur Systematik und Funktion der Signalisierung von Intertextualität. Heidelberg: Universitätsverlag C. Winter.

Herwig, H. (2002). Literaturwissenschaftliche Intertextualitätsforschung im Spannungsfeld konkurrierender Intertextualitätsbegriffe. Zeitschrift für Semiotik, 24(2-3): 163-76.

Hohl Trillini, R. and Langlotz, A. (2008). The grammar of 'to be or not to be'. In Csaba Földes (ed.), Phraseologie disziplinär und interdisziplinär. Tübingen: Günter Narr, pp. 155-66.

Holthuis, S. (1993). Intertextualität: Aspekte einer rezeptionsorientierten Konzeption. Tübingen: Stauffenburg.

Holthuis, S. (1994). Intertextuality and meaning constitution: an approach to the comprehension of intertextual poetry. In Petöfi, J. S. and Olivi, T. (eds), Approaches to Poetry: Some Aspects of Textuality, Intertextuality and Intermediality. Berlin: Walter de Gruyter, pp. 77-93.

Jenny, L. (1982). The strategy of form. In Todorov, T. (ed.), French Literary Theory Today: A Reader. Cambridge: Cambridge University Press, pp. 24-63.

Klein, J. and Fix, U. (1997). Vorwort. In Klein, J. and Fix, U. (eds), Textbeziehungen: Linguistische und literaturwissenschaftliche Beiträge zur Intertextualität. Tübingen: Stauffenburg, pp. 7-18.

Kristeva, J. (1967). Bakhtine, le mot, le dialogue et le roman. Critique, 33(239): 438-65.

Laak, M. and Viires, P. (2004). Intertextuality and technology: The models of Kalevipoeg. In Grishakova, M. and Lehtimäki, M. (eds), Intertextuality and Intersemiosis. Tartu: Tartu University Press, pp. 287-312.

Lachmann, R. (1984). Ebenen des Intertextualitätsbegriffs. In Stierle, K. and Warning, R. (eds), Das Gespräch. München: Wilhelm Fink, pp. 133-8.

Landow, G. P. (2006). Hypertext 3.0: Critical Theory and New Media in an Era of Globalization. Baltimore: Johns Hopkins University Press.

Langlotz, A. (2006). Idiomatic Creativity: A Cognitivelinguistic Model of Idiom Representation and Idiom Variation in English. Amsterdam: John Benjamins.

Lennon, P. (2004). Allusions in the Press: An Applied Linguistic Study. Berlin: Mouton de Gruyter.
Lewis, C. S. (1969). The literary impact of the authorised version. In Hooper, W. (ed.), C. S. Lewis: Selected Literary Essays. Cambridge: Cambridge University Press, pp. 126-45.

McGann, J. The rationale of hypertext. http://jefferson. village.virginia.edu/public/jjm2f/rationale.html. No posting or update date given (accessed 15 May 2008).

Meyer, H. (1968). T. Ziolkowski and Y. Ziolkowski (trans.), Poetics of Quotation in the European Novel. Princeton, NJ: Princeton University Press.

Morawski, S. (1970). The basic functions of quotation. In Greimas, A. J. et al. (eds), Sign, Language, Culture. The Hague: Mouton, pp. 690-705.

Morgan, T. (1985). Is there an intertext in this text? Literary and interdisciplinary approaches to intertextuality. American Journal of Semiotics, 4: 1-40.

Müller, W. G. (1991). Interfigurality: a study on the interdependence of literary figures. In Plett, H. F. (ed.), Intertextuality. Berlin: Walter de Gruyter, pp. 101-19.

Orr, M. (2003). Intertextuality: Debates and Contexts. Oxford: Polity Press.

Perri, C. (1978). On alluding, Poetics, 7: 289-307.

Petöfi, J. S. and Olivi, T. (1988). Von der verbalen Konstitution zur symbolischen Bedeutung. Hamburg: Helmut Buske.

Pfister, M. (1985). Konzepte der Intertextualität. In Broich, U. and Pfister, M. (eds), Intertextualität: Formen, Funktionen, anglistische Fallstudien. Niemeyer: Tübingen, pp. 1-30.

Plett, H. F. (1985). Sprachliche Konstituenten einer intertextuellen Poetik. In Broich, U. and Pfister, M. (eds), Intertextualität: Formen, Funktionen, anglistische Fallstudien. Niemeyer: Tübingen, pp. 78-97.

Plett, H. F. (1988). The poetics of quotation. Annales Universitatis scientiarum Budapestinensis: Sectio Linguistica, 17: 293-313.

Quassdorf, S. and Hohl Trillini, R. (2008). Quotations and their $\operatorname{co}(\mathrm{n})$ texts: corpus-based insights into discoursing with Hamlet. Variability and Change in Language and Discourse, RANAM, 41: 75-89.

Riffaterre, M. (1994). Intertextuality vs. hypertextuality. New Literary History, 25: 779-88.

Schahadat, S. (1995). Intertextualität: Lektüre - Text Intertext. In Pechlivanos, M. (ed.), Einführung in die Literaturwissenschaft. Stuttgart: Metzler, pp. 366-77.

Scollon, R. (2004). Intertextuality across communities of practice: academics, journalism and advertising. In Moder, C. L. and Martinovic-Zic, A. (eds), 
Discourse Across Languages and Cultures. Amsterdam: John Benjamins, pp. 149-76.

Stern, L. (1980). On interpreting. The Journal of Aesthetics and Art Criticism, 39(2): 119-29.

Sternberg, M. (1982). Proteus in quotation-land: Mimesis and the forms of reported discourse. Poetics Today, 3(2): 107-56.

Stierle, K. (1984). Werk und intertextualität. In Stierle, K. and Warning, R. (eds), Das Gespräch. München: Wilhelm Fink, pp. 139-50.

Stocker, P. (1998). Theorie der intertextuellen Lektüre: Modelle und Fallstudien. Paderborn: Ferdinand Schöningh.

Taylor, G. (1989). Reinventing Shakespeare: A Cultural History from the Restoration to the Present. London: Vintage.

Tsur, R. (1998). Biblical allusion and cognitive processes. http://www.tau.ac.il/ tsurxx/inlay_2a.html (acessed 23 November 2007).

Weise, G. (1997). Zur Spezifik der Intertextualität in literarischen Texten. In Klein, J. and Fix, U. (eds), Textbeziehungen: Linguistische und literaturwissenschaftliche Beiträge zur Intertextualität. Tübingen: Stauffenburg, pp. 39-48.

Wheeler, M. (1979). The Art of Allusion in Victorian Fiction. London: Macmillan.

Wray, A. (2002). Formulaic Language and the Lexicon. Cambridge: Cambridge University Press.

\section{Notes}

1 The original reads: 'nicht einmal diese [...] Haupttypen [können] voneinander geschieden werden [weil] die Relationen in ihrer Fülle so kaum noch unterscheidbar und praktisch handhabbar sind' (Heinemann 1997, 35).

2 The parameter approach has been suggested before, but these studies either lack a broad database (Broich, 1985; Androutsopoulos, 1997; Grüttemeier, 2000) or neglect to consider parameter interaction (Plett, 1988; Weise, 1997; Hebel, 1989).

3 Wolfgang Heinemann claims to have found 48 meanings or uses of 'intertextuality' or 'intertextual' (21).

4 Cf. the title of Klein and Fix, 1997, which translates as 'Text Relations'.

5 Genette also includes 'paratextuality' (e.g. the relations between texts and their titles), which is not relevant here.
6 For example the title, which refers to a phrase in Hamlet's letter to Ophelia: 'Thine evermore [...] whilst this machine is to him, Hamlet' (act 2, scene 2).

7 The term 'Phrase' is used for Quoted Elements ranging from single words to complete clauses because phrases are the most frequent quotation size.

8 An operational distinction of conventional genres such as travesty, parody and pastiche according to their affirmative and critical attitudes (Herwig, 2002, 172) or 'authentication of' and 'separation from [...] authorities' (Orr, 2003, 17) is as yet outstanding.

9 Heinemann does not give the bibliographical reference for this article.

10 For example, 'a regulation more honoured in the breach than the observance' can be considered as a version of Shakespeare's noun phrase 'a custom more honoured in the breach than the observance', since 'regulation' and 'custom' stem from a comparable semantic field. If, on the other hand, 'Frailty-thy name is woman' becomes 'Vanity, thy name is Hodges' (in an episode of the Tv series CSI) - it is the structural parallelism which makes regard the changed nouns as substitutes and the whole clause as a modified Quoted Element.

11 The original reads: 'aus heuristischen Gründen lediglich die explizite Markierung und die "graphemischen Interferenzen" [zu nutzen]'.

12 Quotation marks and anomalies, the most blatant signals of intended intertextual reference, have accumulated terminologies and bibliographies of their own. Linguistic terms describing for MARKING phenomena are, amongst others: 'contextual priming' (cf. Hohl Trillini and Langlotz, 2008), 'deictic' (Plett, 1988), '(re-) anchoring devices', 'quotatives', 'laminators', 'quotation formulae', 'embedding', and 'framing' (cf. Bolden, 2004 for a summary). Anomalies have been called 'code interference' (Plett, 1988), or 'interferential text surface' (Holthuis, 1994).

13 Cf. the sophisticated set of parameters suggested in Pfister (1985): 'dialogicity' is expressive of a tension in values, ideology and semantics, 'communicativity' is the quality of intentionally setting signals which the reader can decode, and 'autoreflexivity' is signalled by metacommunicative devices which indicate that the quoted element is thematized by the later text itself.

14 The original reads: 'diejenigen Formen der Intertextualität in die Sinnbildung einzubeziehen, die nicht intentional in den Text hineingelegt worden sind, vielleicht unbewusster Bestandteil des kulturellen Wissens des Verfassers und seiner Prägung durch die Diskursformation seiner Zeit waren' (Herwig, 2002, 170). 
15 The original reads: 'A la place de la notion d'intersubjectivité s'sinstalle celle d'intertextualité'.

16 The original reads: 'ob ein Autor einen bestimmten Text gekannt hat, ob er sich bewusst und intentional auf ihn bezieht und ob er die Kenntnis des Prätexts und die Fähigkeit, den Rekurs auf ihn zu erkennen, auch beim Leser voraussetzt'.

17 That is, through recurrent supporting references from Hamlet, other Shakespeare plays or references to theatrical life or the Elizabethan period (see Quassdorf and Hohl Trillini, 2008).
18 The predominant interests of the HyperHamlet database have led to a few modifications in the case of Relation Type. For the convenience of users, the type 'integrated' is represented by a number of more conventional, roughly Genettian search categories; 'suffused' texts are given a ReLATION Type of their own, 'Recurrent references', and 'listed' and 'discussed' are pulled together as 'citation'. The possibility of multiple ReLation Types for any given entry in the database is given. 